\title{
Identification and Categorization of Building Defects
}

\author{
Omar Mostafa Alomari \\ Department of Architecture, College of Engineering, Al-Balqa Applied University, Jordan
}

Received November 22, 2021; Revised January 12, 2022; Accepted February 8, 2022

\section{Cite This Paper in the following Citation Styles}

(a): [1] Omar Mostafa Alomari, "Identification and Categorization of Building Defects," Civil Engineering and Architecture, Vol. 10, No. 2, pp. 438-446, 2022. DOI: 10.13189/cea.2022.100204.

(b): Omar Mostafa Alomari (2022). Identification and Categorization of Building Defects. Civil Engineering and Architecture, 10(2), 438-446. DOI: 10.13189/cea.2022.100204.

Copyright $\bigcirc 2022$ by authors, all rights reserved. Authors agree that this article remains permanently open access under the terms of the Creative Commons Attribution License 4.0 International License

\begin{abstract}
The problem of building defects is one of the common problems that occur throughout the lifecycle of the building. The construction stakeholders consider it a critical issue that led to costs and time implications of reworks. Mostly, repairing construction defects requires a cost approximately ranging from $2.4 \%$ to $3.15 \%$ of the total cost of building. Therefore, the current study looks forward to discovering and classifying the common factors contributing to construction defects. To achieve this objective, the researcher adopted a qualitative method to collect and analyze the needed data through deep review of several previous studies that focused on the causes of building defects. Accordingly, this study identified 57 common contributing factors of building defects, which are classified into five groups according to their sources. These groups are Factors related to design, Factors related to construction, Factors related to materials, Factors related to human and External factors. Understanding the contributing factors of the building defects can help construction stakeholders take and develop various strategies to reduce the existence of defects in newly constructed buildings. Positively, the findings of this study could upgrade the management efficiency of the building defects assessment process in the future, which will help to avoid them as much as possible.
\end{abstract}

Keywords Causes, Building Defects, Construction, Design, Factors

\section{Introduction}

In recent years, the demand for buildings has increased globally due to the growth of the population around the world [1]. In addition, the past years have seen many technological developments, which encourage the building occupants to focus more on the safety and suitability of the buildings to achieve the requirements of satisfactory living. Therefore, people are increasingly interested in providing quality housing facilities for functionality and beauty due to developments in various sectors [2]. The fundamental purpose of a building is to protect its users and contents from various external elements, specifically, wind, extremes of temperature and rain [3]. This requires that all elements of the building be able to achieve the required protection. According to Poles, GC, RCI, \& Times. [4], to survive, the construction must be structurally sound, and the floors able to withstand any loads normally imposed. Thus, to ensure the long-term safety and quality of the building, the causes of defects must be avoided [5].

It is worth noting that some flaws in the building cause other defects. The condition of a building component or system installed in it may also impact the overall condition of the building [6]. In fact, most latent defects manifest themselves only during the occupancy stage, and it can be challenging to gain access to occupied buildings to gather information on these defects [7]. In addition, the repair of these defects requires enormous funds to repair them. Therefore, it is necessary to research the causes of these defects in order to reduce them during the design and implementation stages.

There are various definitions for defects, as stated in several studies. The defect, according to Webster's Dictionary, is defined as the absence of something necessary for completeness [3]. Besides, ISO 15686-1 states that a defect is an error or deviation from the intended performance level of a building or its parts [8]. On the other hand, a building defect can be any issue that decreases the worth of a building [3]. Defects, according to 
Ojo and Ijatuyi [9], are errors that may minimize the strength, sturdiness, or helpfulness of a construction work. Consequently, building defects can be defined as issues that lower the building specification standards and, therefore, the value of the building.

Building defects can endanger building occupants or users, as well as jeopardize the safe operation and use of building facilities [6]. These risks need many repairs, which means additional costs. Aside from the product's final cost, the construction of a defective building has repercussions throughout the life cycle of the building in the form of maintenance costs [10]. Building defects, in particular, have a significant influence on construction time, cost, sustainability, output and satisfaction of customers [11]. Furthermore, if these issues persist, those working in the construction industry will be subjected to a slew of processes and regulations before starting their work [3]. Therefore, it is necessary to consider the critical causes of building defects to reduce the risk of defects.

Therefore, the first step in resolving any building defect problem is the correct diagnosis of the cause [12]. Consequently, it is essential to define the source of the issues and then find a solution to them [13]. Therefore, the current study focuses on identifying the serious factors that give rise to defects in construction buildings. This is done by reviewing various literature that dealt with the causes of building defects. Besides, this paper presents the most prominent causes of construction defects by grouping them into main groups according to the sources of these causes. To better understand the impact of defects, it is necessary to classify them. Furthermore, a defect classification is essential for parties who want to file a claim against a builder or another party [14].

\section{Literature Review}

\subsection{Building Defects}

Construction defects are a common phenomenon in the world, which are the key to the attention of the construction industry [15]. Therefore, construction defects are one of the significant construction issues that need great consideration [16]. The majority of countries are suffering from building defects despite the variety in their conditions. For example, "defects and deviations from standards in construction products are a persistent source of worry in Ghana's construction industry," write Baiden and Tuuli [17]. In addition, Kazaz and Bir Gonul [18], in their study in Turkey, pointed out that in the construction industry, satisfaction with the quality level is not achieved, which is a serious problem. It is clear that construction defects are a common occurrence in most buildings worldwide.

A construction defect is defined as a failure of a building component to be installed properly. According to Yacob, Ali, \& Au-Yong. [5], they are defined as flaws in anything that detracts from faultlessness, whereas damage to a building occurs when construction work or building elements are not fully effective. Accordingly, the appearance of defects in the building reduces the quality of the building. One of the hindrances to the project's success is quality, while poor quality during the construction phase helps in the occurrence of many defects [13]. As known, in the construction context, poor quality can mean that project goal cannot be achieved, or that customer needs are not being met.

In addition to reducing the quality, defects also lead to additional costs. It is clear that the costs of defects have a noteworthy impact on construction project cost performance [19]. For example, Mills, Love, \& Williams. [20] stated that defect costs accounted for $4 \%$ of the cost of the new construction contracts. Whereas, Love and $\mathrm{Li}$ [21] found that the defective costs of residential and industrial buildings were $3.15 \%$ and $2.40 \%$, correspondingly. Accordingly, it can be concluded that the cost of defects in buildings is considered a significant percentage. Therefore, it is necessary to seek to find the suggestions required to reduce building defects, and this is by identifying the leading causes of defects.

The study by Yacob et al. [5] mentioned that building defects are a problem faced by most buildings, regardless of building construction techniques or age, but it all depends on the causes and factors that cause the defects to occur. The significance of various construction defects has been established, and their importance to building maintenance is recognized [22]. Building defects can be caused by an architectural design error, a manufacturing defect, the use of inferior materials, improper use of materials, a contractor's failure to comply with the design, or any combination of these factors [3]. Furthermore, it was discovered by Waziri [23] that several construction defects could be fully explained or partially by easily identifiable construction errors that could have been predicted and thus avoided. It is worth noting that various causes have been identified in different studies. Hence, the current study focused on collecting these reasons and arranging them in several groups according to their sources.

Regarding defective buildings, the most common hurdle is recovering the costs of rectifying defects discovered before physical damage occurs [24]. According to several studies, the cost of construction defects ranges between 5 and $10 \%$ of the production cost [22]. Defects can occur during the construction process, as well as during the delivery and residence. Furthermore, Chong and Low [25] reported that defects discovered during the construction and occupancy phases are usually distinct. While some defects are latent during the construction phase, they are not visible and cannot be identified until the buildings are used.

\subsection{Factors Causing Building Defects}

Globally, the number of aged buildings is increasing, and in most countries, this is attended by a raise in building defects and associated costs [26]. A construction defect can 
reduce and affect the worth of the buildings. Building defects, in particular, reduce the lifespan of buildings, endanger the safety and health of users, and prevent buildings from performing their functions properly [21\& 27]. Thus, the presence of defects leads to a reduction of the value of the buildings. It is worth noting that these defects are not limited to a specific stage. In their study, Forcada et al. [28] confirmed that the defects detected at each stage of the building life cycle (construction, handover, post-handover, and maintenance) are different. Defects occur as a result of different causes in terms of the source, where these reasons vary in the degree of danger to the building. A defect's cause is a time-dependent event that causes parts, elements, components, and building materials to fail.

Construction defects are caused by various factors, some of which are observable to the eye and others that are acutely unseen within the structure. Some construction defects that directly affect the performance of structures are caused by poor design or construction [23]. Construction failures and defects can also occur because of the use of inappropriate materials, poor production, or misunderstanding of different designs [22]. Ilozor, Okoroh, and Egbu [29] demonstrated that some defects lead to the appearance of other defects, and therefore preventing the main defects can prevent the appearance of many defects. Hence, it is necessary to detect the factors that contribute to the construction defects at the early stage to avoid further defects from occurring. According to several studies, various types of building defects were classified according to their source or effects.

For example, Bakri and Mydin [16] classified defects into two types: structural defects and non-structural defects. A structural defect is a defect that appears in a structural element, which is the result of a specific defect in materials or designs, or both [3]. On the other hand, the structural defects in the foundation and structural instability are due to over-stressing. A building's structure consists of columns, earth retaining walls, fat slabs, and beams [22]. In contrast, non-structural defects in the building are any defects in the non-structural elements of the building that do not compromise the structural integrity of the building, which include defects in brickwork, moisture and defects in various finishes.

On the other hand, Lee, Lee, and Kim. [30] classified defects into eight categories according to the causes of their occurrence, which are as follows: poor job performance, cracked objects, abrasion, separation, improper fitting, missing mission, surface appearance, and water issues. In addition, in another study [31], construction defects also are classified into four types: design flaws, material flaws, construction flaws, and geotechnical issues. It is worth noting that the effects of defects are described as slight, "minor", "moderate" or even very severe [32]. As a starting point for defining degree, the Building Research Establishment suggests three broad categories of 'aesthetic', 'serviceability' and 'stability [15]. Another study by Hauashdh, Jailani, Rahman, and Al-Fadhali. [33] also classified building defects into seven types, namely Defects related to building structural elements, Defects related to technical installation and technology use, Defects related to (HVAC) system, Defects related to the water supply system, Defects related to the transportation system, Defects related to building services, Defects related to the fire system. It is clear from the different classifications in previous studies that there are various and multiple defects throughout the life cycle of the building, as each study relies on a specific basis for classifying defects, which confirms that the building defects are different and multiple.

Additionally, the study by Hauashdh et al. [33] outlined the significant factors affecting the number of building defects in Malaysian Public Universities' Buildings. It also classified the factors affecting the building defects into eight types, which are factors relevant to building design, factors relevant to building materials specifications, factors relevant to maintenance contractors, factors relevant to defects inspection and detection, factors relevant to building users' awareness, factors relevant to building's age, factors relevant to the type of building function and factors relevant to types of building services. Concerning determining the most defective components of the building, the study conducted by Wali and Ali [34] found that the most components were doors and windows, which came in the first place at a percentage of $75 \%$, followed by painting and painting the doors in the second place at $75 \%$, and in the third place were cracks in the structural elements by $73 \%$.

In the construction industry, two factors are rarely considered: the buildability of the design and the materials' durability. The first one specifies whether good workmanship can ever be achieved if the necessary reasonable care and skill are present and the cost of the design. Second, the materials' durability, which represents the life span of each material in a given environment before it deteriorates, either partially or completely [35].

Many previous literature review results showed multiple reasons for building defects that differ from one study to another. For instance, the study by Summerlin and Ogborn [36] revealed that construction defects could be caused by an architectural design error, manufacturing defect, inferior materials, improper use of materials, or failure to comply with blueprints and specifications. According to the level of importance, the main contributing reasons for defects are low material quality, poor workmanship, design flaws, and occupants' lack of awareness [37]. Furthermore, Ahzahar et al. [3] discovered that the most popular cause of building defects is poor construction material quality. The study by Ramli et al. [38], which aimed to identify common building defects in heritage buildings in Malaysia, revealed that the common causes are cracks in concrete and brick walls, timber defects, dampness and salt attack, and defective plaster and paint. 


\begin{tabular}{|l|l|l|l|l|}
\hline \multicolumn{1}{|c|}{ Design stage } & Construction stage \\
\hline $\begin{array}{l}\text { - Design errors } \\
\text { - materials \& methods } \\
\text { - No consideration of } \\
\text { constructability } \\
\text { - Insufficient design documents }\end{array}$ & $\begin{array}{l}\text { - Lack of material performance } \\
\text { - Poor supervision \& } \\
\text { inspection } \\
\text { - Omission of product parts } \\
\text { - Poor workmanship } \\
\text { - Non compliance with spec. }\end{array}$ & $\begin{array}{l}\text { - Poor temperature and } \\
\text { humidity control } \\
\text { - No curing material followed } \\
\text { - Damage caused by other } \\
\text { work } \\
\text { - Insufficient curing time }\end{array}$ & $\begin{array}{l}\text { - No regular inspection } \\
\text { - Damage due to natural } \\
\text { disasters. etc. }\end{array}$ \\
\hline $\begin{array}{l}\text { - Lack of integrated communication among project patiicipants } \\
\text { - Lack of integrated project quality management }\end{array}$ & - Careless use of residents \\
\hline - Frequent change order of project owners & Before service \\
\hline
\end{tabular}

Figure 1. Causes of building defects through the lifecycle of building, Source (Yoon, Son, \& Kim, 2021)

According to the study conducted by Chong and Low [25], most of the defects related to human factors are $29 \%$ due to forgetfulness, neglect and lack of knowledge, while a small percentage were intended. On the other hand, Seeley [39] notes that design errors are responsible for $58 \%$ of defects, operational and installation errors cause $35 \%$, poor materials and systems cause $12 \%$, and $11 \%$ result from unexpected user requirements. Besides, A Ransom [40] survey found that wear and tear represented $56 \%$ of all defects explored. In comparison, poor design decisions accounted for $20 \%$, and materials and workmanship accounted for $20 \%$.

Many studies have indicated that the causes of building defects appear throughout the life cycle of the building from its inception to its use. The study by Yoon, Son, and Kim [41] summarized various causes of building defects through a comprehensive review of previous studies, which are classified according to the stages of the building's life cycle as shown in Figure 1, which includes the design stage, construction stage, curing stage, and operation and maintenance stage.

Based on the results of the study by Kian [42], four critical factors contribute to building defects, such as improper loading in the build phase, lack of knowledge about building elements, incorrect identification of the cause of the defect and failure to perform the required maintenance, failure to connect and join for items. Previous research by Talib, Ahmad, Zakaria, \& Sulieman. [43] found that factors affecting building defects include inadequate building maintenance, neglected site status, defective materials, building ageing, poor quality control, the nonexistence of training, absence of motivation, poor communication, environmental situations, and a moisture problem.

\section{Methodology}

This study focuses on the categorization of the factors that influence building defects. To achieve the objective of this study, data were collected from several previous studies that dealt with the causes of building defects. Since the research objectives require in-depth exploration and research, the qualitative approach of the current study is the most appropriate because it refers to the results of previous studies about the title of the study. Accordingly, several previous studies were deeply reviewed to explore the common causes of building defects. The methodology of the study includes two main phases. In the first phase, several previous studies that dealt with the causes of building defects were collected. Through a deep review of these studies, the researcher collected around 57 causes of building defects. Phase two of this study focused on classifying the collected causes in groups based on their source. According to the comprehensive review conducted in this research, the researcher suggested the main groups within which the causes can be arranged, where the causes arising from the same source were arranged in one group. Based on this, the researcher identified five groups of factors, namely Factors related to design, Factors related to construction, Factors related to materials, Factors related to human and External factors.

\section{Results and Discussion}

According to an in-depth review of previous studies that investigated factors contributing to construction defects, 57 critical factors were collected and categorized into various groups according to their source. The common factors in the source were grouped into one group, and accordingly, they were classified into five groups, as shown in Figure 2. The factors included in each group are discussed in the following sub-sections. 


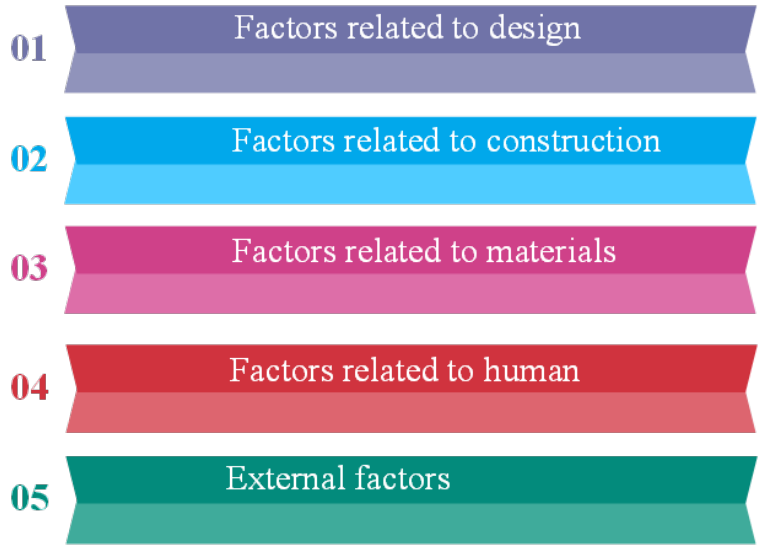

Figure 2. Groups of factors contribution to building defects

\subsection{Factors Related to Design}

This group includes seven factors that are related to building design, as summarized in Table 1 .

Table 1. Factors related to design

\begin{tabular}{cc}
\hline ID & Factors \\
\hline A1 & $\begin{array}{c}\text { Misinterpretation of the design leading to wrong } \\
\text { construction. }\end{array}$ \\
A2 & $\begin{array}{c}\text { Exceeding the allowable limits of verticality of the } \\
\text { structural elements. }\end{array}$ \\
A3 & Using inadequate concrete mix design for structural \\
elements.
\end{tabular}

The design stage is vital in the construction life cycle, as good preparation for this stage significantly reduces construction defects. Therefore, several studies considered design deficits as major contributors to building defects. According to the study by Chong and Low [7], nearly 50 to $60 \%$ of building defects are attributed to design flaws or would have been avoidable with better design. On the other hand, some studies have confirmed that building design impacts building defects, building maintenance, building performance, and user satisfaction [27, 44, 45]. Insufficient information, ignorance, incorrect expectations, lack of knowledge were recognized by Minato [46] as contributing factors to defects in the design stage. A faulty design can also result from poor judgment, which leads to expectations or decisions that do not correspond to the actual behavior of the structure [47]. Non-compliance with specifications, unqualified designers, lack of communication between designers and contractors, lack of quality management during design, design errors, inappropriate specifications, and conflicting details on drawings, on the other hand, were revealed as the causes of design defects in [34].
Another study by Chong and Low [7] provided several criteria to prevent design-related defects. These can effectively help to avoid the appearance of design-related defects, which consist of adapting the performance of the material to adverse weather conditions, avoiding the effects from loads and occupants, preventing water leakage, optimizing specifications and improving design clarity, detail and planning. Furthermore, Anand, Vasudevan, \& Ramamurthy. [48] proposed that improved design could correct some defects resulting from workmanship in construction work. According to Khalid et al. [45]; Salim, Salleh, and Zahari. [49], Maintenance planning during the design process reduces the usual number of defects and maintenance costs.

It is worth noting that the availability of sufficient information for the design engineer effectively contributes to choosing the appropriate type of design for the building, which thus prevents many defects resulting from inappropriate design. Therefore, the current study suggests focusing on the outputs of the design phase, as it is the first step in the life cycle of any building.

\subsection{Factors Related to Construction}

This group includes 19 factors that are related to the construction process, as summarized in Table 2.

Table 2. Factors related to construction

\begin{tabular}{|c|c|}
\hline ID & Factors \\
\hline B1 & Inaccurate dimension projection and measurement. \\
\hline $\mathrm{B} 2$ & $\begin{array}{l}\text { Damaged or weak formwork due to the multiuse of } \\
\text { formwork timber. }\end{array}$ \\
\hline B3 & $\begin{array}{l}\text { Ignoring isolation works for buried parts of concrete } \\
\text { (footings, ground beams and walls). }\end{array}$ \\
\hline B4 & Poor roof water drainage system. \\
\hline B5 & Insufficient reinforcement concrete cover. \\
\hline B6 & $\begin{array}{l}\text { Cold joints, especially in concrete casting, due to late } \\
\text { concrete arrival. }\end{array}$ \\
\hline B7 & $\begin{array}{l}\text { Poor soil compaction or backfilling without compaction } \\
\text { and layers. }\end{array}$ \\
\hline B8 & $\begin{array}{l}\text { Inadequate water curing of different concrete and } \\
\text { finishing works. }\end{array}$ \\
\hline B9 & $\begin{array}{l}\text { Overloading of the building during the construction } \\
\text { stage. }\end{array}$ \\
\hline B10 & $\begin{array}{l}\text { Use of inexperienced or poorly qualified/unspecialized } \\
\text { labour. }\end{array}$ \\
\hline B11 & $\begin{array}{l}\text { Not complying with specification and engineer } \\
\text { instructions. }\end{array}$ \\
\hline B12 & Absence of engineers in most of the construction phases. \\
\hline B13 & Speedy completion or poor-quality work. \\
\hline B14 & Errors in construction. \\
\hline B15 & $\begin{array}{l}\text { Construction not according to design or the exposure of } \\
\text { the building to factors not allowed for in the design. }\end{array}$ \\
\hline B16 & $\begin{array}{l}\text { Deficient application of the ventilation and thermal } \\
\text { insulation elements. }\end{array}$ \\
\hline B17 & $\begin{array}{l}\text { Incorrect handling of materials or use of inadequate } \\
\text { tools. }\end{array}$ \\
\hline B18 & Incorrect application of sealants. \\
\hline B19 & $\begin{array}{l}\text { Badly executed casting joint in architectural concrete } \\
\text { surfaces. }\end{array}$ \\
\hline
\end{tabular}


The construction phase in buildings includes many construction processes that need monitoring and control to ensure the quality of construction. Therefore, most of the causes of building defects result from errors, negligence or lack of control during the construction process. The previous study conducted by Tayeh et al. [22] aimed to identify the factors affecting the occurrence of defects in the construction phase of the residential buildings in the Gaza Strip. The result of the study found the most five important factors, namely building materials, factors caused by inspections, factors caused by construction equipment, factors caused by construction and factors caused by construction management [22]. Furthermore, Assaf, Al-Hammad, and Al-Shihah. [50] reported other defects, which include (1) defects caused by construction inspection, (2) defects caused by civil construction, (3) defects caused by specification, (4) defects caused by contractor administration, (5) defects caused by construction material, and (6) defects caused by construction equipment.

The construction phase is a complex phase during the building life cycle. It includes many interrelated activities that need effective management to organize activities within the required specifications without affecting the quality of the building and its elements. For example, the wrong implementation of the various insulation works leads to the building's exposure to multiple defects that indirectly affect the performance of other activities such as painting and plasterwork. In addition, misinterpretation of drawings and specifications is one of the common causes of building defects.

\subsection{Factors Related to Materials}

This group includes nine factors that are related to construction materials, as summarized in Table 3.

Table 3. Factors related to materials

\begin{tabular}{cc}
\hline ID & Factors \\
\hline C1 & Lack of inspection and material testing \\
C2 & $\begin{array}{c}\text { Using of expired material. } \\
\text { C3 }\end{array}$ \\
C4 & $\begin{array}{c}\text { Pelection of material that is unsuitable for existing } \\
\text { climatic conditions. }\end{array}$ \\
C5 & Manufacturing process or improper installation of \\
material. \\
C6 & Metal corrosion. \\
C7 & Defects in materials. \\
C8 & Inappropriate materials applied to the building. \\
C9 & Use of deficient materials due to the manufacturing \\
process.
\end{tabular}

In construction, various types of materials are used, which need more attention from the users to ensure their quality and use. This needs good information and awareness of the construction materials to avoid any building defects. Based on the study by Ahzahar et al. [3], the most common cause of building defects and failures is poor quality construction materials. In addition, the use of materials during the construction stage is expected to determine the future behavior of building defects; thus, construction materials are relevant to building defects. Furthermore, according to research conducted in Singapore, "the most common defects found are primarily due to poor workmanship quality" [25].

According to $\mathrm{Xu}, \mathrm{Li}, \mathrm{Li}$, and $\mathrm{Li}$. [51], the use of low-quality or inferior materials, improper maintenance, and material ageing can cause defects during the building operation, which needs further investigation. Nevertheless, verifying the materials' quality and sustainability during the building construction process is critical to avoiding defective materials and reducing future maintenance waste $[7,52,53]$. As a result, managing the sustainability and quality of materials during construction can be accomplished through adequate supervision to ensure that the chosen materials are not defective, that their properties are suitable for use under different conditions, and that there will be no negative consequences from using them after the building's construction is complete [7\& 54].

There are several causes for construction defects related to materials, such as improper use of materials and non-compliance with the company's manufacturing instructions. Also, the inexperience of professionals with the components and efficiency of the materials used leads to construction defects appearing in the later stages. Moreover, in recent years, many environmentally friendly materials have appeared, characterized by their efficiency and ability to treat defects that occur during the implementation stages and thus reduce defects during the occupancy stage.

\subsection{Factors Related to Human}

This group includes 13 factors that are related to humans, as summarized in Table 4.

Table 4. Factors related to human

\begin{tabular}{cc}
\hline ID & Factors \\
\hline D1 & Lack of awareness by occupants. \\
D2 & Lack of knowledge. \\
D3 & Lack of supervision, poor expert decision making. \\
D4 & Building location. \\
D5 & Failure to carry out necessary maintenance. \\
D6 & Inadequate inspection. \\
D7 & Dwelling orientation. \\
D8 & Inadequate information, unawareness, wrong \\
D9 & assumptions, and lack of knowledge. \\
D10 & Change of the originally planned use conditions. \\
D11 & Insufficient ventilation. \\
D12 & Incorrect handling of the movable parts. \\
D13 & Locking mechanism in door and window frames. \\
\hline
\end{tabular}

Some defects in the building are directly interrelated to 
the behavior of the users. As a result, awareness is a factor that can influence user behavior in order to reduce building defects [33]. According to Vondráčková, Voštová, and Nývlt. [55], human error is an unintended or insufficient decision made at any level of an organization's hierarchy. Nevertheless, Chong \& Low [25] discovered that most of the defects due to human factors were solely occurring due to forgetfulness and carelessness. Moreover, the operators' wrong use of the buildings may cause the appearance of various defects in the building facilities. In most cases, these defects are not related to poor materials or workmanship. Also, there are various defects caused by the lack of knowledge and awareness of the construction contributors. Therefore, the various construction works must be monitored by specialized engineers to avoid any human errors during implementation. Also, a good project is dependent on how it is handled by professionals such as project managers, contractors, engineers, architects, and so on [56].

One of the most prominent human factors that lead to construction defects is the wrong decisions taken by those involved in the construction during the construction implementation cycle. For example, making wrong decisions in choosing the appropriate site for construction, choosing professionals, choosing materials and equipment. Therefore, reviewing with experts before making decisions helps avoid many causes of construction defects.

\subsection{External Factors}

This group includes nine factors that are related to external factors, as summarized in Table 5 .

Table 5. External factors

\begin{tabular}{cc}
\hline ID & Factors \\
\hline E1 & Climatic condition. \\
E2 & Environmental conditions. \\
E3 & Soil condition \\
E4 & Movements of structural nature of walls or foundations \\
E5 & Impacts of heavy objects resulting from inclement \\
E6 & weather \\
E7 & Vibrations \\
E8 & Abrasion \\
E9 & Infestation by woodworms or termites in wood floorings \\
\hline
\end{tabular}

The study by Silva et al. [56] indicated that construction had been one of the biggest polluters since it began. Therefore, the concept of environmental sustainability has sparked transformational changes in the built environment, intending to reduce environmental impact, resource extraction, and energy consumption levels throughout building life cycles [57]. To achieve environmental sustainability in building defect management, adopting sustainable maintenance of building defects is required, beginning with reducing defect occurrences, then using sustainable materials during maintenance practices, and finally utilizing defect repair waste $[2,30,53]$.

All construction work must be done in accordance with the requirements of operational safety, economic efficiency, and environmental sensitivity [55]. Nevertheless, throughout the life cycle of the building, its elements are exposed to many external factors such as weather and environmental factors that cannot be controlled. As a result, many defects appear that sometimes affect the use of the building and thus reduce its value. Dampness in buildings, for example, is one of the most damaging failures that can lead to a variety of other defects or issues [58], ultimately leading to the deterioration of buildings and affecting their functions. Furthermore, due to the process of expansion and contraction, buildings tend to crack with age. To reduce the effects of these building defects, periodic maintenance of all facilities is necessary, as some defects, if not addressed, will lead to other defects and may be more dangerous.

\section{Conclusions}

This study shows that several building defects differ in their source and effects. Consequently, the current study focuses on categorizing the building defects in different groups according to their origins. Furthermore, this research shows that it is possible to minimize building defects by identifying their common causes. Based on the data collected for building defects, the factors related to design and factors related to the construction stage are the most prevalent factors that contribute to building defects. Hence, it is essential to certify the building design's accuracy and reality before starting its execution. Furthermore, it is suggested to all parties involved in the construction process to conduct control programs in their project to reduce the factors that lead to building defects as possible. In addition, the current study confirms the need to focus on the periodic maintenance of buildings, which avoids many defects. The study also suggested improving construction techniques and using environmentally friendly materials during the construction phases of buildings.

Besides, the study's findings can help builders understand the most common causes of building defects. Classification of the causes of construction defects helps understand the causes and thus avoid them. Based on the result of the study, stakeholders can take appropriate corrective actions or develop a mitigation plan to reduce the occurrence of the major causes of defects in newly constructed buildings. Also, the current study can be used as a database for other studies to analyze the causes of building defects to find other types of defects. Thus, other researchers can extend the current study to include other 
factors which could influence the building defects. On the other hand, the results of this study can be based for further studies to search about the mitigations of the building defects.

\section{REFERENCES}

[1] D. Sherbinin, D. Carr, S. Cassels, \& L. Jiang. Population and Environment. Annu. Rev. Environ. Resour., 32, 345-373, 2007.

[2] P. O. Akadiri, E. A. Chinyio, \& P. O. Olomolaiye. Design of a sustainable building: A conceptual framework for implementing sustainability in the building sector. Buildings, 2(2), 126-152, 2012.

[3] N. Ahzahar, N. Karim, S. Hassan, \& J. Eman. A study of contribution factors to building failures and defects in construction industry. Procedia engineering, 20, 249-255, 2011.

[4] M. S. Poles, C. M. GC, D. RCI, \& A. Times. What Are Construction Defects? In, 2008.

[5] S. Yacob, A. S. Ali, \& C. P. Au-Yong. Establishing Relationship Between Factors Affecting Building Defects and Building Condition. Journal of Surveying, Construction and Property, 10(1), 31-41, 2019.

[6] F. Faqih, T. Zayed, \& E. Soliman. Factors and defects analysis of physical and environmental condition of buildings. Journal of Building Pathology and Rehabilitation, $5,1-15,2020$.

[7] W. K. Chong, \& S. P. Low. Latent building defects: causes and design strategies to prevent them. Journal of performance of constructed facilities, 20(3), 213-221, 2006.

[8] ISO 15686-1, Buildings and constructed assets-service life planning. Int Organ Stand (ISO), 2000.

[9] A. Ojo, \& O. Ijatuyi. Defective construction in residential buildings: a study of sunshine gardens, Akure Nigeria. International Journal of Civil Engineering, Construction and Estate Management, 1(2), 16-30, 2014.

[10] P. E. Josephson, \& L. Saukkoriipi. Slöseri i byggprojekt: behov av förändrat synsätt. Retrieved from, 2005.

[11] F. E. Rotimi, J. Tookey, \& J. O. Rotimi. Evaluating defect reporting in new residential buildings in New Zealand. Buildings, 5(1), 39-55, 2015.

[12] S. Wahab, \& M. Hamid. A review factors affecting building defects of structural steel construction. Case study: Student accommodation in UiTM Perak. Procedia engineering, 20, 174-179, 2011

[13] A. S. Ali, \& K. H. Wen. Building defects: Possible solution for poor construction workmanship. Journal of Building Performance, 2(1), 2011.

[14] N. Johnston, \& S. Reid. An examination of building defects in residential multi-owned properties, 2019.

[15] M. I. M. Hasan, N. N. Abd Razak, I. R. Endut, S. A. A. Samah, A. R. M. Ridzuan, \& S. Saaidin. Minimizing defects in building construction project. Jurnal Teknologi, 78(5-2), 2016.

[16] N. N. O. Bakri, \& M. A. O. Mydin. General building defects: causes, symptoms and remedial work. European Journal of Technology and Design (1), 4-17, 2014.

[17] B. K. Baiden, \& M. M. Tuuli. Impact of quality control practices in sandcrete blocks production. Journal of Architectural Engineering, 10(2), 53-60, 2004.

[18] A. Kazaz, \& M. T. Birgonul. Determination of quality level in mass housing projects in Turkey. Journal of Construction Engineering and Management, 131(2), 195-202, 2005.

[19] C. S. Park, D. Y. Lee, O. S. Kwon, \& X. Wang. A framework for proactive construction defect management using BIM, augmented reality and ontology-based data collection template. Automation in construction, 33, 61-71, 2013.

[20] A. Mills, P. E. Love, \& P. Williams. Defect costs in residential construction. Journal of Construction Engineering and Management, 135(1), 12-16, 2009.

[21] P. E. Love, \& H. Li. Quantifying the causes and costs of rework in construction. Construction Management \& Economics, 18(4), 479-490, 2000.

[22] B. A. Tayeh, A. Maqsoom, Y. I. A. Aisheh, M. Almanassra, H. Salahuddin, \& M. I. Qureshi. Factors affecting defects occurrence in the construction stage of residential buildings in Gaza Strip. SN Applied Sciences, 2(2), 1-12, 2020.

[23] B. S. Waziri. Design and construction defects influencing residential building maintenance in Nigeria. Jordan Journal of Civil Engineering, 10(3), 2016.

[24] N. Rajendra, \& J. Philip. Tort liability for Defective Construction Work. Current Issue Facing the Construction Industry. Society of Construction Law \& Arbitration Conference, 2004

[25] W. K. Chong, \& S. P. Low. Assessment of defects at construction and occupancy stages. Journal of performance of constructed facilities, 19(4), 283-289, 2005.

[26] M. Park, N. Kwon, J. Lee, S. Lee, \& Y. Ahn. Probabilistic maintenance cost analysis for aged multi-family housing. Sustainability, 11(7), 1843, 2019.

[27] A. Hauashdh, J. Jailani, \& I. A. Rahman. Building maintenance practices in Malaysia: a systematic review of issues, effects and the way forward. International Journal of Building Pathology and Adaptation, 2020.

[28] N. Forcada, M. Macarulla, M. Gangolells, \& M. Casals. Handover defects: comparison of construction and post-handover housing defects. Building Research \& Information, 44(3), 279-288, 2016.

[29] B. Ilozor, M. Okoroh, \& C. Egbu. Understanding residential house defects in Australia from the State of Victoria. Building and Environment, 39(3), 327-337, 2004.

[30] S. Lee, S. Lee, \& J. Kim. Evaluating the impact of defect risks in residential buildings at the occupancy phase. Sustainability, 10(12), 4466, 2018.

[31] S. Yang, \& Y. M. Ro. Visual contents adaptation for color vision deficiency. Paper presented at the Proceedings 2003 International Conference on Image Processing (Cat. No. 03CH37429), 2003. 
[32] J. D. Mollon, S. M. Hood, L. Purves, \& G. Jordan. Color discrimination in carriers of color deficiency. Journal of Vision, 4(11), 9-9, 2004.

[33] A. Hauashdh, J. Jailani, I. A. Rahman, \& N. Al-Fadhali. Factors affecting the number of building defects and the approaches to reduce their negative impacts in Malaysian public universities' buildings. Journal of Facilities Management, 2021.

[34] K. I. Wali, \& N. S. Ali. Diagnosis and Evaluation of Defects Encountered in Newly Constructed Houses in Erbil City, Kurdistan, Iraq. Engineering and Technology Journal, 37(2), 70-77, 2019.

[35] M. J. Swain, \& D. H. Ballard. Color indexing. International journal of computer vision, 7(1), 11-32, 1991.

[36] Summerlin \& Ogborn. Construction Defects. Construction Law Attorneys, Thomson Business, 2006.

[37] A. Awol. Assessment on Causes of Defect and the Maintenance Management Practices on Low Cost Building (A Case Study of Jimma Town Condominium). International Journal of Engineering and Technical Research, 151-156, 2016.

[38] M. A. Ramli, M. A. Kamarazaly, L. X. Shi, F. I. Ibrahim, \& M. Rizal. Building Defects and Restoration Techniques of Heritage Buildings in Malaysia. Malaysian Construction Research Journal (MCRJ), 76, 2021.

[39] I. H. Seeley. Building maintenance, 2nd Ed., Macmillan, London, 1987.

[40] W. H. Ransom. Building failures: Diagnosis and avoidance: Routledge, 2002.

[41] S. Yoon, S. Son, \& S. Kim. Design, Construction, and Curing Integrated Management of Defects in Finishing Works of Apartment Buildings. Sustainability, 13(10), 5382,2021

[42] P. S. Kian. A Review of Factors Affecting Building Defects in Singapore. Dimensi Teknik Sipil, 3(2), 64-68, 2001.

[43] R. Talib, A. G. Ahmad, N. Zakaria, \& M. Z. Sulieman. Assessment of factors affecting building maintenance and defects of public buildings in Penang, Malaysia. Architecture Research, 4(2), 48-53, 2014.

[44] S. N. H. Ishak, A. H. Chohan, \& A. Ramly. Implications of design deficiency on building maintenance at post-occupational stage. Journal of Building Appraisal, 3(2), 115-124, 2007.

[45] E. I. Khalid, S. Abdullah, M. H. Hanafi, S. Y. Said, \& M. S. Hasim. The consideration of building maintenance at design stage in public buildings: The current scenario in Malaysia. Facilities, 2019.
[46] T. Minato. Representing causal mechanism of defective designs: a system approach considering human errors. Construction management and economics, 21(3), 297-305, 2003.

[47] R. W. Brown. Practical foundation engineering handbook: McGraw-Hill Education, 2001.

[48] K. Anand, V. Vasudevan, \& K. Ramamurthy. Water permeability assessment of alternative masonry systems. Building and Environment, 38(7), 947-957, 2003.

[49] N. A. A. Salim, N. M. Salleh, \& N. F. Zahari. Design failure affecting maintenance management on public higher education institution in Malaysia. Paper presented at the MATEC Web of Conferences, 2016.

[50] S. Assaf, A. M. Al-Hammad, \& M. Al-Shihah. Effects of faulty design and construction on building maintenance. Journal of performance of constructed facilities, 10(4), 171-174, 1996.

[51] Z. Xu, S. Li, H. Li, \& Q. Li. Modeling and problem solving of building defects using point clouds and enhanced case-based reasoning. Automation in construction, 96, 40-54, 2018.

[52] A. Coelho, \& J. De Brito. Influence of construction and demolition waste management on the environmental impact of buildings. Waste management, 32(3), 532-541, 2012.

[53] G. Kanniyapan, L. J. Nesan, I. S. Mohammad, T. S. Keat, \& V. Ponniah. Selection criteria of building material for optimising maintainability. Construction and Building Materials, 221, 651-660, 2019.

[54] A. S. Asmone, S. Conejos, \& M. Y. Chew. Green maintainability performance indicators for highly sustainable and maintainable buildings. Building and Environment, 163, 106315, 2019.

[55] T. Vondráčková, V. Voštová, \& V. Nývlt. The human factor as a cause of failures in building structures. Paper presented at the MATEC Web of Conferences, 2017.

[56] D. Silva, B. Villaverde, K. L. De Jesus, L. Marcial Jr, R. L. Ejera, C. V. Villa-Real, \& J. M. Zarraga. Design Initiative Implementation Framework: A Model Integrating Kolmogorov-Smirnov in Sustainable Practices for Triple-Bottom-Line Principles in Construction Industry. Civil Engineering and Architecture, 8(4), 599-617, 2020. DOI: $10.13189 /$ cea.2020.080424.

[57] J. K. W. Wong, \& J. Zhou. Enhancing environmental sustainability over building life cycles through green BIM: A review. Automation in construction, 57, 156-165, 2015.

[58] N. L. Othman, M. Jaafar, W. M. W. Harun, \& F. Ibrahim. A case study on moisture problems and building defects. Procedia - Social and Behavioral Sciences, Vol. 170, pp. 27-36, 2015. 